97 Fall MRS Meetıng

Boston, MA

Symposium KK

\title{
Study of the Effects of $\mathrm{MeV} \mathrm{Ag}, \mathrm{Cu}, \mathrm{Au}$, and $\mathrm{Sn}$ Implantation on the Optical Properties of $\mathrm{LiNBO}_{3}$
}

E. K. Williams, D. Ila, S. Sarkisov, and M. Curley

Alabama A\&M University

Normal, AL

D. B. Poker and D. K. Hensley

Oak Ridge National Laboratory

Oak Ridge, TN

C. Borel

ite Claude Bernard

Universite Claude
Lyon, France

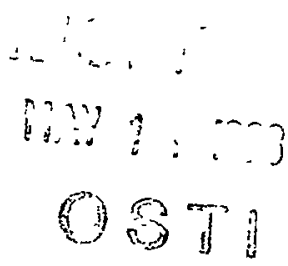

"The submitted manuscript has been authored by a contractor of the US

Government under contract No DEAC05-960R22464 Accordingly, the U.S Government retains a nonexclusive, royalty-free license to publish or reproduce the published form of this contnbution, or allow others to do so, for U S Government purposes,"

Prepared by the

Oak Ridge National Laboratory

Oak Ridge, Tennessee 37831

managed by

LOCKHEED MARTIN ENERGY RESEARCH CORP.

for the

U.S. DEPARTMENT OF ENERGY

under contract DE-AC05-960R22464

February 1998 


\section{DISCLAIMER}

This report was prepared as an account of work sponsored by an agency of the United States Government. Neither the United States Government nor any agency thereof, nor any of their employees, make any warranty, express or implied, or assumes any legal bability or responsibility for the accuracy, completeness, or usefulness of any information, apparatus, product, or process disclosed, or represents that its use would not infringe privately owned rights. Reference herein to any specific commercial product, process, or service by trade name, trademark, manufacturer, or otherwise does not necessarily constitute or imply its endorsement, recommendation, or favoring by the United States Government or any agency thereof. The views and opinions of authors expressed herein do not necessarily state or reflect those of the United States Government or any agency thereof. 
STUDY OF THE EFFECTS OF MEV AG, CU, AU AND SN IMPLANTATION ON THE OPTICAL PROPERTES OF LINBO

EK WILLIAMS", D ILA*, S SARKISOV*, M CURLEY", D.B POKER**, D. K. HENSLEY* ${ }^{*}$ C BOREL"

*Dept. of Natural and Physical Sciences, PO Box 1447, Normal, AL 35762-1447,

**Solid State Division, Oak Ridge National Laboratory, Oak Ridge, TN 37831,

***Université Claude Bernard, Lyon, France

\section{ABSTRACT}

We present the results of characterization of linear absorption and nonlinear refractive index of $\mathrm{Au}, \mathrm{Ag}, \mathrm{Cu}$ and $\mathrm{Sn}$ ion implantation into $\mathrm{LiNbO}_{3} . \mathrm{Ag}$ was implanted at $1.5 \mathrm{MeV}$ to fluences of 2 to $17 \times 10^{16} / \mathrm{cm}^{2}$ at room temperature. Au and $\mathrm{Cu}$ were implanted to fluences of 5 to $20 \mathrm{x}$ $10^{16} / \mathrm{cm}^{2}$ at an energy of $20 \mathrm{MeV} \mathrm{Sn}$ was implanted to a fluence of $1.6 \times 10^{17} / \mathrm{cm}^{2}$ at $160 \mathrm{kV}$ Optical absorption spectrometry indicated an absorption peak for the Au implanted samples after heat treatment at $1000^{\circ} \mathrm{C}$ at $\sim 620 \mathrm{~nm}$ The $\mathrm{Ag}$ implanted samples' absorption peaks shifted from $\sim 450 \mathrm{~nm}$ before heat treatment to $550 \mathrm{~nm}$ after $500^{\circ} \mathrm{C}$ for $1 \mathrm{~h}$ Heat treatment at $800^{\circ} \mathrm{C}$ returned the $\mathrm{Ag}$ implanted crystals to a clear state. $\mathrm{Cu}$ nanocluster absorption peaks disappears at $500^{\circ} \mathrm{C}$ No Sn clusters were observed by opotical absorption or XRD The size of the Ag and Au clusters as a function of heat treatment were determined from the absorption peaks $\mathrm{The} A \mathrm{Ag}$ clusters did not change appreciably in size with heat treatment The Au clusters increased from 3 to $9 \mathrm{~nm}$ diameter upon heat treatment at $1000^{\circ} \mathrm{C}$. TEM analysis performed on a Au implanted crystal indicated the formation of Au nanocrystals with facets normal to the c-axis.

Measurements of the nonlinear refractive indices were carried out using the Z-scan method with a tunable dye laser pumped by a frequency doubled mode-locked Nd.YAG laser. The dye laser had a 45 ps pulse duration time and $76 \mathrm{MHz}$ pulse repetition rate $(575 \mathrm{~nm})$

INTRODUCTION

Introducing metal colloids into a glass or other transparent material matrix has been used to change their color for decoration and more recently for fabricating optical filters and other fast optical devices In recent years, ion implantation has been used to introduce nonlinear optical properties [1-10] in layers near the surface of optical materials. To form nanoclusters after ion implantation the material may need to be thermally annealed or laser annealed [11]. An attractive feature of ion implantation is that the metal colloids can be placed in a well defined space near the surface and that by using focused ion beams, point quantum confinement may be accomplished

It has long been known that small metallic particles or colloids embedded in dielectrics produce colors associated with optical absorption at the surface plasmon resonance frequency $[12,13]$ For a collection of spherical clusters with diameters much smaller than the wavelength of the incident light the absorption coefficient $\left(\mathrm{cm}^{-1}\right)$ of the composite can be calculated from [12]

$$
\alpha=\frac{18 \pi Q n_{o}^{3}}{\lambda} \frac{\varepsilon_{2}}{\left(\varepsilon_{1}+2 n_{o}^{2}\right)^{2}+\varepsilon_{2}^{2}}
$$

where $Q$ is the volume fraction occupied by the metallic particles, $n_{0}$ is the refractive index of the host medium, and $\varepsilon_{1}$ and $\varepsilon_{2}$ are the real and imaginary parts of the frequency-dependent 
dielectric constant of the bulk metal Equation 1 is maximized at the surface plasmon resonance frequency $\left(\omega_{\mathrm{p}}\right)$ when $\varepsilon_{1}=-2 \mathrm{n}^{2}$ if $\varepsilon_{2}$ is well behaved in this region.

Using tabulated values $[14,15]$ of $\varepsilon_{1}$ for $\mathrm{Cu}, \mathrm{Sn}, \mathrm{Ag}$ and $\mathrm{Au}$ as a function of the photon wavelength, and using $\mathrm{n}_{0}=2.2$, Equation 1 predicts that the wavelengths for the surface plasmon resonance frequencies should be about $520 \mathrm{~nm}$ for $\mathrm{Ag}$ and near $620 \mathrm{~nm}$ for $\mathrm{Cu}$ and $\mathrm{Au}$ and at $\sim 350 \mathrm{~nm}$ for $\mathrm{Sn}$

If the metal spheres are small compared with the wavelength of the incident light, their radius estimated from the optical absorption spectrum is $r=A_{m} v_{f} / \Delta \omega_{1 / 2}[1,16]$, where $v_{f}$ is the Fermi velocity of the metal and $\Delta \omega_{1 / 2}$ is the full width at half maximum of the absorption band and $A_{m}$ is a constant that varies for different metals. For $A g$ we have taken $A_{m}=1$ and for $A u$ we have used $A_{m}=1.5$ [16].

\section{EXPERIMENTAL PROCEDURES}

Single crystal, $1 \mathrm{~mm}$ thick $\mathrm{LiNbO}_{3}$ wafers were obtained from Crystal Technology Inc., (Palo Alto, CA). We used 1.5 MeV Ag and $2.0 \mathrm{MeV} \mathrm{Au}$ and $\mathrm{Cu}$ with beam currents of 2 to 3 $\mu \mathrm{A} / \mathrm{cm}^{2}$ and the samples were maintained at room temperature $\mathrm{Ag}$ was implanted to fluences ranging from $2 \times 10^{16} / \mathrm{cm}^{2}$ to $1.7 \times 10^{17} / \mathrm{cm}^{2}$ while Au and Cu were implanted from $5 \times 10^{16} / \mathrm{cm}^{2}$ to $20 \times 10^{17} / \mathrm{cm}^{2}$. Sn was implanted at $160 \mathrm{keV}$ to fluences up to $1.6 \times 10^{17} / \mathrm{cm}^{2}$.

Optical absorption photospectrometry was done soon after implantation and immediately after heat treatment using a Cary model $3 \mathrm{e}$ spectrophotometer. Heat treatments were done in air at temperatures of $300^{\circ} \mathrm{C}$ to $1000^{\circ} \mathrm{C}$ for times from 0.5 to 14 hours. Average radii were measured from these spectra.

To investigate the effects of the implantation on the third order nonlinear optical coefficient, $\mathrm{n}_{2}$, we used the $\mathrm{z}$-scan technique $[17,18]$ employing a tunable pulsed dye laser pumped by a frequency doubled mode locked Nd.YAG laser run to give a wavelength of $575 \mathrm{~nm}$ and a pulse width of $4.5 \mathrm{ps}$ at a repetition rate of $76 \mathrm{MHz}$. The average power was 70 to $350 \mathrm{~mW}$, giving a power density applied to the sample in the range of 0.02 to $0.1 \mathrm{GW} / \mathrm{cm}^{2}$.

\section{RESULTS AND DISCUSSION.}

The damage and modification of the optical properties are directly proportional to the atomic number and fluence of the bombarding ion $[19,20]$. The $\mathrm{LiNbO}_{3}$ samples implanted with $\mathrm{Ag}$ at fluences of less than $8 \times 10^{16} / \mathrm{cm}^{2}$ were yellow/brown immediately after implantation but turned blue after $1 \mathrm{hr}$ heat treatment at $500^{\circ} \mathrm{C}$, whereas a sample implanted at $1.7 \times 10^{17} / \mathrm{cm}^{2}$ remained almost black The gold samples were much darker and changed to a dark purple after heat treatment at temperatures above $700^{\circ} \mathrm{C}$. The lower fluence $\mathrm{Cu}$ samples were red and the $\mathrm{Sn}$ implanted samples were light to dark gray The surfaces of all of the $\mathrm{Ag}$ implanted samples were also noticeably textured by the implantation; the higher fluence samples even functioned as poor quality diffraction gratings The Au implanted $\mathrm{LiNbO}_{3}$ also showed some surface texturing but not to the same extent as the $\mathrm{Ag}$ samples The texturing remained in the $2 \times 10^{17} \mathrm{Au} / \mathrm{cm}^{2}$ sample after 10 hours at $1000^{\circ} \mathrm{C}$.

The absorption spectra for $\mathrm{Cu}$ and $\mathrm{Sn}$ implanted $\mathrm{LiNbO}_{3}$ are shown in Figure 1. The peak due to $\mathrm{Cu}$ clusters disappears after $500^{\circ} \mathrm{C}$ heat treatment for one hour. After $400^{\circ} \mathrm{C}$ for $1 \mathrm{~h}$ in air the $\mathrm{Sn}$ spectrum is the same as a virgin crystal. RBS analysis of the Sn implanted sample shown no significant diffusion at these low temperatures XRD analysis did not indicate the presence of Sn crystals

The absorption spectra from a Ag implanted sample at a fluence of $5 \times 10^{16} / \mathrm{cm}^{2}$ is shown in Figure 2 The absorption peaks decreased in height and shifted to longer wavelengths, with the 


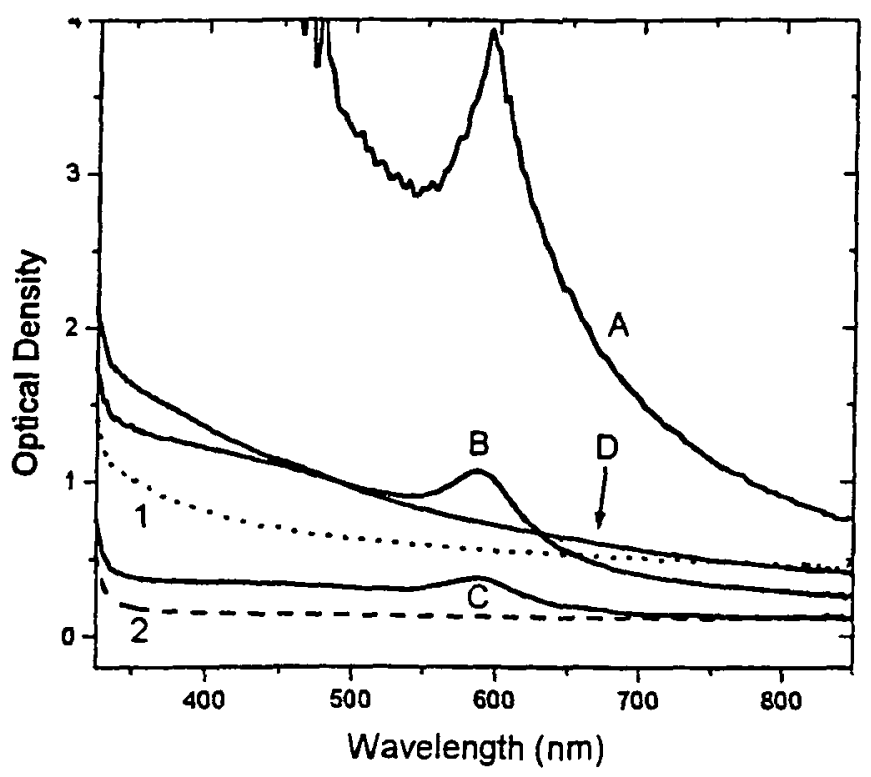

Figure 1 Optical absortion spectra from 20 Mev Cu, A) $2 \times 10^{17} / \mathrm{cm}^{2}$, B) $5 \times 10^{17} / \mathrm{cm}^{2}$, C) 2 $\times 10^{16} / \mathrm{cm}^{2}$, D) $2 \times 10^{17} / \mathrm{cm}^{2}$ heated to $500^{\circ} \mathrm{C}$ and from $160 \mathrm{keV} \mathrm{Sn}, 16 \times 10^{17} / \mathrm{cm}^{2}$. 1) As Implanted, 2) $400^{\circ} \mathrm{C}, 1 \mathrm{hr}$

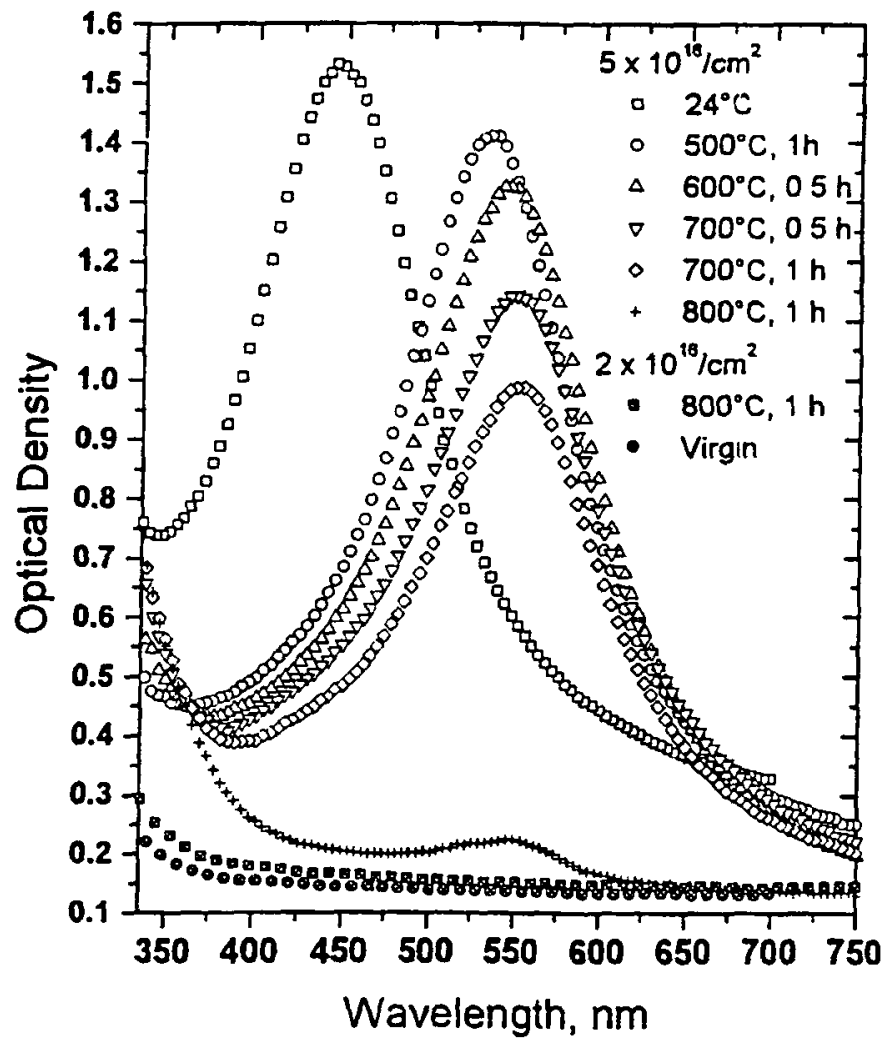

Figure 2 Optical absortion spectra of 15 $\mathrm{MeV} \mathrm{Ag}$ implanted $\mathrm{LiNbO}_{3}$ after various heat treatments The calculated radius increased from $11 \mathrm{~nm}$ at $24^{\circ} \mathrm{C}$ to $16 \mathrm{~nm}$ at $700^{\circ} \mathrm{C}$ greatest shift occuring during the initial $500^{\circ} \mathrm{C}$ heat treatment. After $800^{\circ} \mathrm{C}$ heat treatment the $2 \times 10^{16} \mathrm{Ag} / \mathrm{cm}^{2}$ implanted sample's absorption spectrum was very close to that of a virgin crystal. The change in height of the spectra may be due to a reduction in the number of $\mathrm{Ag}$ clusters as $\mathrm{Ag}$ diffuses atomistically into the substrate The wavelengths of the $\mathrm{Ag}$ absorption peaks and the radii of the clusters are shown in Table 1 for each fluence and heat treatment. The radii are intially the same for all three fluences, then increase from 30 to 60 percent after heat treatment. Another increase in radius is seen just before the aborption spectra disappear.

In the as-implanted state the absorption peaks were at a wavelength shorter than that expected from theory $(\sim 520 \mathrm{~nm})$. This blue shift may be caused primarily by end of range damage, which has been shown [23] to decrease the index of refraction by over 5 percent. From Equation 1, changing the host index by 5 to 10 percent would result in a shift of the expected absorption peak of 20 to $40 \mathrm{~nm}$ Heat treatment works to remove much of this implantation damage and restores the refractive index $\mathrm{LiNbO}_{3}$ implanted with $\mathrm{Ag} 1 \times 10^{17} / \mathrm{cm}^{2}$ at $190 \mathrm{keV}$ has been shown to undergo full epitaxial regrowth after heat treatment at $400^{\circ} \mathrm{C}$ [24], but an anneal of $800^{\circ} \mathrm{C}$ for $1 \mathrm{~h}$ is necessary for full removal of the implantation damage. Prism coupling results indicate that for a Ag fluence of $2 \times 10^{16} / \mathrm{cm}^{2}$ and heat treatment at $500^{\circ} \mathrm{C}$ the refractive index is increased by over 5 percent, sufficient to move the plasmon resonance peak position from the expected $520 \mathrm{~nm}$ to the expenmentally observed $542 \mathrm{~nm}$

The absorption spectra for a $5 \times 10^{16}$ $\mathrm{Au} / \mathrm{cm}^{2}$ implanted sample is shown in Figure 3 No absorption peak is visible pror to heat treatment There was little 


\begin{tabular}{|c|c|c|c|}
\hline $\begin{array}{l}\text { Fluence, } \\
\text { ions } / \mathrm{cm}^{2}\end{array}$ & $\begin{array}{c}\text { Temp } \\
{ }^{\circ} \mathrm{C}\end{array}$ & $\begin{array}{c}\text { Optical } \\
\text { Density at } \\
575 \mathrm{~nm}\end{array}$ & $\begin{array}{c}\text { Nonlinear } \\
\text { index, } \mathrm{n}_{2}, 10^{-8} \\
\mathrm{~cm}^{2} / \mathrm{W}\end{array}$ \\
\hline $2 \times 10^{16}$ & 500 & 0.39 & 0.96 \\
\hline $2 \times 10^{16}$ & 800 & 0.15 & 0.35 \\
\hline $5 \times 10^{16}$ & 500 & 1.0 & 2.90 \\
\hline $5 \times 10^{16}$ & 800 & 0.2 & 0.38 \\
\hline $17 \times 10^{16}$ & 500 & 1.87 & 6.81 \\
\hline
\end{tabular}

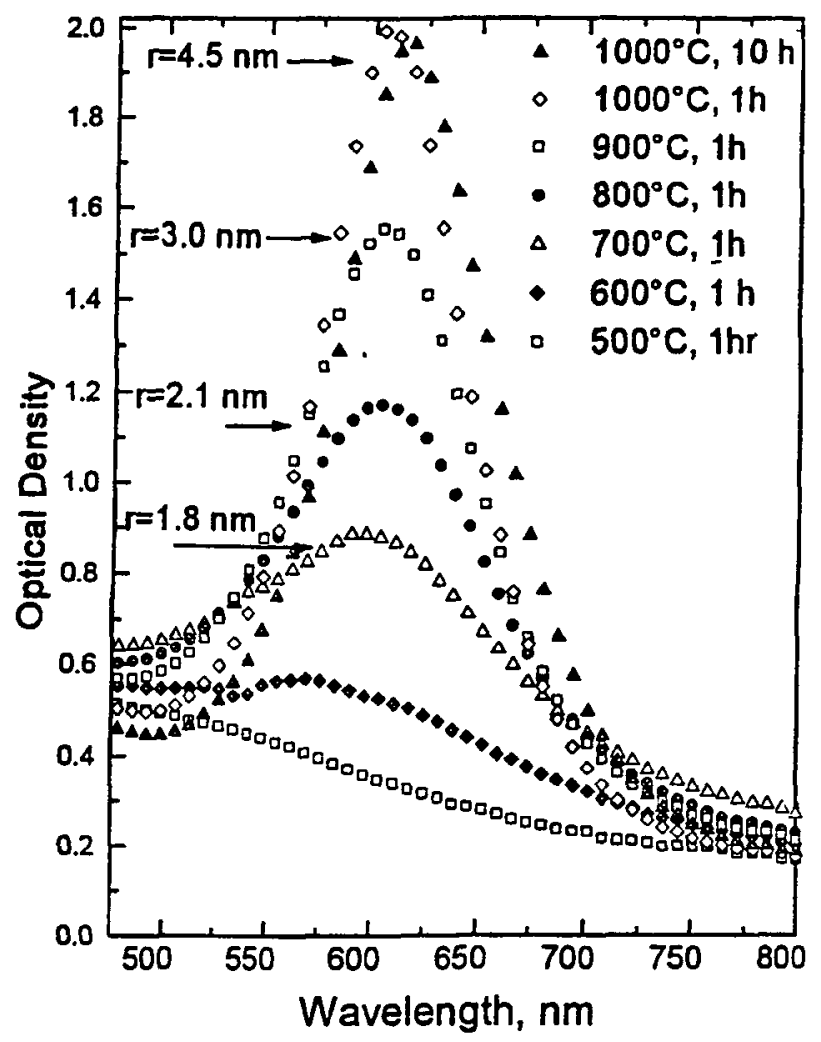

change in the spectrum from the $5 \times 10^{16}$ $\mathrm{Au} / \mathrm{cm}^{2}$ sample after 0.5 and $14 \mathrm{~h}$ at $500^{\circ} \mathrm{C}$ but for higher fluence samples $\left(9 \times 10^{16} / \mathrm{cm}^{2}\right.$ and $2.0 \times 10^{17} / \mathrm{cm}^{2}$ ) the $500^{\circ} \mathrm{C}$ for $0.5 \mathrm{~h}$ heat treatment resulted in an absorption spectrum

Figure 3. Optical absorption spectra from $5 \times 10^{16} \mathrm{Au} / \mathrm{cm}^{2}$ at $2.0 \mathrm{MeV}$ into z-cut $\mathrm{LiNbO}_{3}$. The radius calculated from each spectrum is indicated. typical of Au. At $700^{\circ} \mathrm{C}$ and above the peak positions shift to longer wavelengths and increase dramatically in height. Shang, et. al. [21] observed a decrease in peak height at $600^{\circ} \mathrm{C}$ for Au implanted into $\mathrm{LiNbO}_{3}$ at $23 \mathrm{keV}$. In their case heat treatment at $600^{\circ} \mathrm{C}$ for up to $8 \mathrm{hr}$ resulted in a blue shift and a large decrease in the peak height with the expectation that the absorption spectrum would disappear with further heat treatment, as is the case for $\mathrm{Ag}$ in $\mathrm{LiNbO}_{3}$. For the two higher fluence samples mentioned above we observed a slight decrease in peak height at $650^{\circ} \mathrm{C}$. Analysis of the absorption spectra indicates that the clusters begin to grow significantly larger at 800 to $900^{\circ} \mathrm{C}$ and appear to reach a maximum size at $1000^{\circ} \mathrm{C}$.

TEM analysis of the $5 \times 10^{16} / \mathrm{cm}^{2}$ Au implanted sample after heat treatment at $1000^{\circ} \mathrm{C}$ for $10 \mathrm{~h}$ shows (Figure 4a) that the Au clusters are in a $\sim 380 \mathrm{~nm}$ thick band $100 \mathrm{~nm}$ below the surface. Figure $4 \mathrm{~b}$ shows the faceting of the Au crystals normal to the c-axis. Very few of the crystals are smaller than $9 \mathrm{~nm}$ in diamter, many are approximately 9 to $11 \mathrm{~nm}$ diameter and they range in size up to $40 \mathrm{~nm}$ in diameter. This agrees reasonably well with the cluster sizes determined from the absorption spectra since in that method the width of the resonance is inversely proportional to the cluster size. The absorption spectrum from mixture of large and small clusters should differ little from the spectrum of small clusters only.

The results of the $\mathrm{z}$-scan for the Ag implanted samples are shown in Table 1. The thickness of the colloidal layer used in the calculation of $\mathrm{n}_{2}(240 \mathrm{~nm}$ for $1.5 \mathrm{Mev} \mathrm{Ag})$ was estimated using SRIM96 [25]. For both $\mathrm{Ag}$ and $\mathrm{Au}$ the magnitude of the nonlinear index increased with increasing fluence and optical density. For the low fluence $\left(2 \times 10^{16} / \mathrm{cm}^{2}\right) \mathrm{Ag}$ implanted sample 
yet a significant postive nonlinear index is seen. This is not the intrinsic nonlinear index of $\mathrm{LiNbO}_{3}$, which is negative, as was confirmed by a z-scan of an unimplanted area. The nonlinear indices reported here are at least one order of magnitude greater than those reported for other silver clusters in the literature [26]. This indicates the presence of the cumulative thermal self-focussing effect which can still occur for the short pulses used in this work due to the . relatively high pulse repetition rate (76 MHz versus $3.8 \mathrm{MHz}$ in Ref. [26]). For the $\mathrm{Au}$ implanted $\mathrm{LiNbO}_{3}$ a positive $\mathrm{n}_{2}$ was seen prior to heat treatment as well as after cluster formation was observed.

\section{CONCLUSIONS}

The $\mathrm{Cu}, \mathrm{Sn}, \mathrm{Ag}$ and $\mathrm{Au}$ implanted $\mathrm{LiNbO}_{3}$ reacted differently to heat treatment as observed in the optical absorption spectra. Silver clusters disappeared at a heat treatment temperature of $800^{\circ} \mathrm{C}, \mathrm{Cu}$ clusters dissappeared at $500^{\circ} \mathrm{C}$ and $\mathrm{Sn}$ clusters were not observed. Heat treatment of the $\mathrm{Au}$ implanted samples was necessary to see the expected absorption spectrum from $\mathrm{Au}$ clusters. Au clusters grew at heat treatment temperatures up to $1000^{\circ} \mathrm{C}$ and formed crystals with facets normal to the c-axis. For $\mathrm{Ag}$ implanted $\mathrm{LiNbO}_{3}$ the $\mathrm{Ag}$ absorption peak appears without heat treatment (Figure 2) and disappears upon heat treatment at $800^{\circ} \mathrm{C}$ but enhancement of the nonlinear index remains after reduction of the absorption.

\section{ACKNOWLEDGMENTS}

This research was supported by the Dept. of Natural and Physical Sciences, Center for Irradiation of Materials, Alabama A\&M University, and the Division of Materials Sciences, U.S. Dept. of Energy, under contract DE-AC05-960R22464 with Lockheed Martin Energy Research Corp. and Alliance for Nonlinear Optics (NASA Grant NAGW-4078).

\section{REFERENCES.}

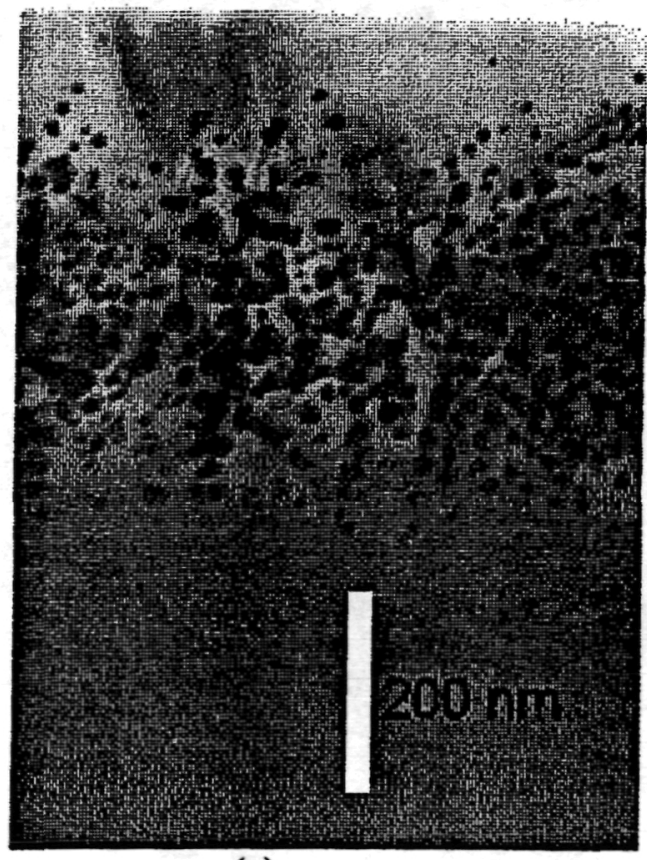

(a)

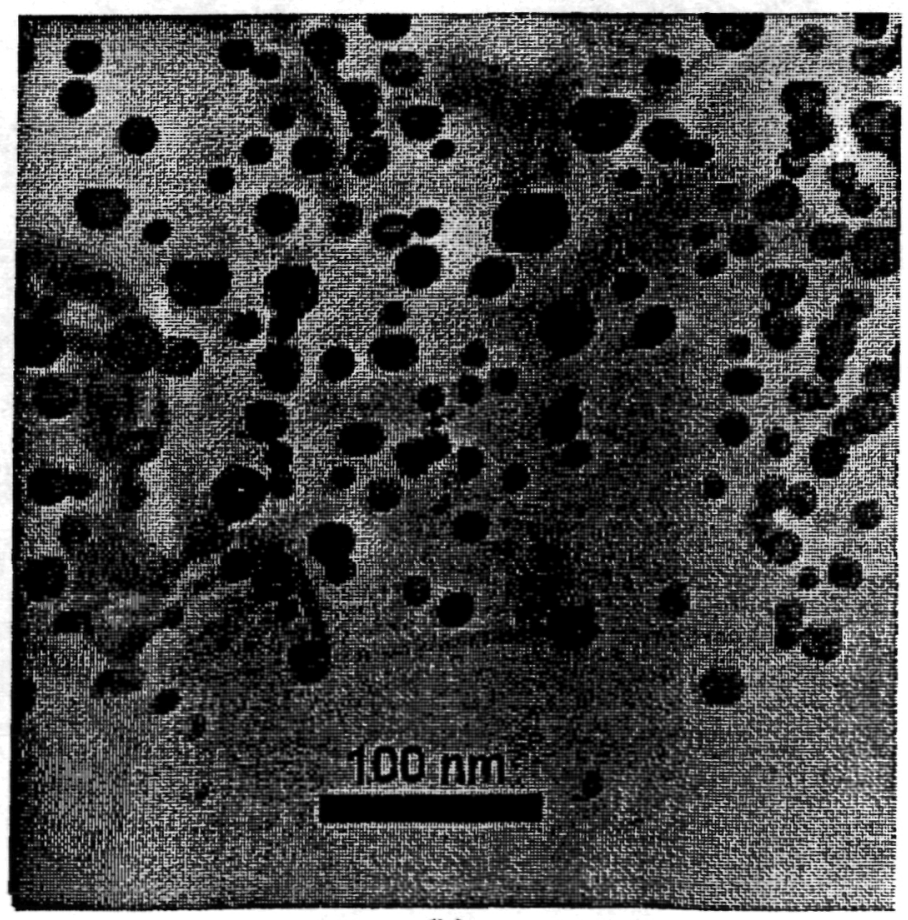

(b)

Figure 4. TEM micrographs of Au clusters in z-cut $\mathrm{LiNbO}_{3}$. The Au fluence was $5 \mathrm{x}$ $10^{16} / \mathrm{cm}^{2}$, heat treatment was $1000^{\circ} \mathrm{C}$ for $10 \mathrm{hr}$. The facets in the Au nanocrystals are normal to the c-axis. 
1. G. W. Arnold, J. Appl. Phys. 46 (1975) 4466.

2. R. H. Magruder III, R. A. Zuhr, D. H. Osborne, Jr., Nucl. Inst. and Meth. B 99 (1995) 590.

3. Y. Takeda, T. Hioki, T. Motohiro, S. Noda and T. Kurauchi, Nucl. Instr. and Meth. B 91, (1994) 515.

4. C. W. White, D. S. Zhou, J. D. Budai, R. A. Zuhr, R. H. Magruder and D. H. Osborné, Mat. Res. Soc. Symp. Proc. Vol 316, (1994)499.

5. K. Fukumi, A. Chayahara, M. Adachi, K. Kadono, T. Sakaguchi, M. Miya, Y. Horino, N. Kitamura, J. Hayakawa, H. Yamashita, K. Fujii and M. Satou, Mat. Res. Soc. Symp. Proc. Vol 235, (1992) 389.

6. D. Ila, Z. Wu, R. L. Zimmerman, S. Sarkisov, C.C. Smith, D. B. Poker, and D. K. Hensley, Mat. Res. Soc. Symp. Proc. Vol 457 (1997) 143.

7. D. Ila, Z. Wu, R. L. Zimmerman, S. Sarkisov, Y. Qian, D. B. Poker, and D. K. Hensley, Mat. Res. Soc. Symp. Proc. Vol 438 (1997) 417.

8. Q. Qian, D. Ila, K. X. He, M. Curley, D. B. Poker, Mat. Res. Soc. Symp. Proc. Vol 396 (1996) 423.

9. D. Ila, Z. Wu, C.C. Smith, D. B. Poker, D. K. Hensley, C. Klatt, and S. Kalbitzer, Nucl. Instr. and Meth. B 127/128 (1997) 570.

10. Y. Qian, D. Ila, R. L. Zimmerman, D. B. Poker, L. A. Boatner, and D. K. Hensley, Nucl. Instr. and Meth. B 127/128 (1997) 524.

11. F. Gonella, G. Mattei, P. Mazzoldi, G. W. Arnold, G. Battaglin, P. Calvelli, R. Poloni, R. Bertoncello, and R. F. Haglund, Jr., Appl. Phys. Lett. 69 (20) 3101.

12. G. Mie, Ann. Physik 25 (1908) 377.

13. J. A. Creighton, D. G. Eadon, J. Chem. Soc. Faraday Trans. 87 (1991) 3881.

14. D. R. Lide, Ed., CRC Handbook of Chemistry and Physics, 76th Ed. (CRC Press, Boca Raton, 1995).

15. E. D. Palik, Ed., Handbook of Optical Constants of Solids (Academic Press, San Diego, 1.985).

16. U. Kreibig and M. Vollmer, Optical Properties of Metal Clusters (Springer Series in Materials Science, Vol25) (Springer Verlag, Berlin, 1995)

17. M. Sheik-bahae, A. A. Said, T. H. Wei, Y. Y. Wu, D. J. Hagan, M. J. Soileau and E. W. van Stryland, SPIE Vol. 1148 Nonlinear Optical Properties of Materials, 41.

18. M. Sheik-bahae, A. A. Said, T. H. Wei, D. J. Hagan and E. W. van Stryland, IEEE J. Quantum Electronics 26 (1990) 760.

19. E. R. Schineller, R. P. Flam and D. W. Wilmot, J. Opt. Soc. Am. 58 (1968) 1171.

20. P. D. Townsend, Nucl. Instr. and Meth. B 46 (1990)18.

21. D. Y. Shang, H. Matsuno, Y. Saito, and S. Suganomata, J. Appl. Phys. 80 (1996) 406.

22. D. Y. Shang, Y. Saito, R. Kittaka, S. Taniguchi and A. Kitahara, J. Appl. Phys. 80 (1996) 6651.

23. P. D. Townsend, Rep. Prog. Phys. 50 (1987) 501.

24. D. B. Poker and D. K. Thomas, Nucl. Inst. and Meth. B 39 (1989) 716.

25. J. F. Zeigler, J. P. Biersack and U. Littmark, The Stopping and Range of Ions in Solids (Pergamon Press, NY, 1985)

26. R. F. Haglund, L. Yang, R. H. Magruder, J. E. Wittig, K. Becker and R. A. Zuhr, Opt. Lett. 18 (1993) 373. 


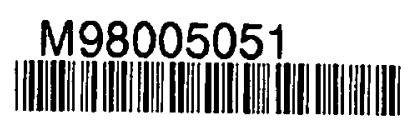

Report Number (14) ORNL/CP--96639

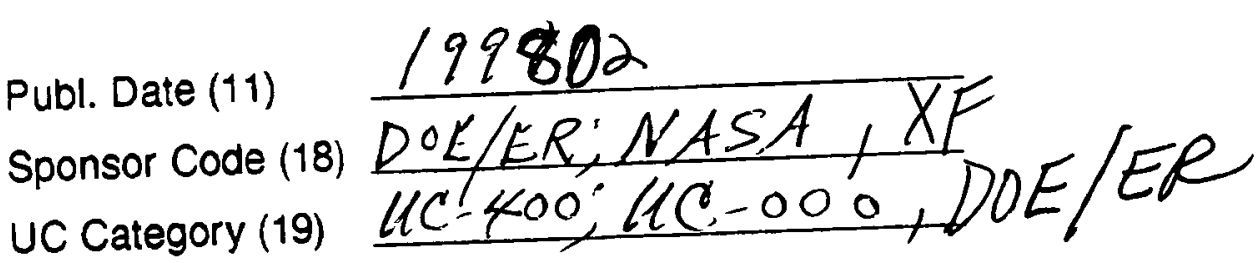

\section{9}

DIIC QUATTIY RIAPECIED I

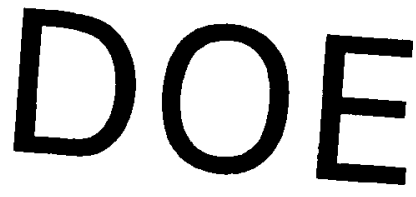

